\title{
Ecocatalyzed Suzuki cross coupling of heteroaryl compounds
}

\author{
Guillaume Clavé ${ }^{\mathrm{a}}$, Franck Pellissier ${ }^{\mathrm{a}}$, Stéphane Campidelli ${ }^{\mathrm{b}}$ and Claude Grison ${ }^{\mathrm{a}}{ }^{*}$
}

\begin{abstract}
A biobased EcoPd was developed for the Suzuki cross coupling of heteroaryl compounds. Based on the ability of Eichhornia crassipes to bioconcentrate Pd in its roots, we addressed the transformation of plant-derived Pd metals to green catalysts. The methodology is based on eco-friendly procedures. It allowed the preparation of a wide range of heterocyclic biaryl and heterocyclic-heterocyclic biaryl compounds, with a low Pd catalyst loading. EcoPd was found to have the ideal microstructure to promote complex Suzuki reactions without ligands or additives. For the first time, post-reaction solution was treated by rhizofiltration. Resulting EcoPd has been reused with the same performances. This work has established the ecocatalysis concept as a powerful strategy for Pd sustainability, with the development of homogeneous catalysts that are easily recycled and reused.
\end{abstract}

\section{Introduction}

Palladium-catalyzed Suzuki cross-coupling is one of the most efficient methods for the synthesis of biaryl compounds. This reaction has profoundly changed methodology for the construction of natural products, building blocks for supramolecular and medicinal chemistry, organic materials and polymers. ${ }^{1-3}$ Consequently, constant efforts are being made to develop new efficient catalytic systems $\mathrm{s}^{4-9}$ and new processes using $\mathrm{Pd}$ homeopathic amounts of $\mathrm{Pd}^{10,11}$. Reactions involving of heteroaryl partners (heteroaryl halides or heteroaryl boronic acids) are less straightforward. Nitrogen and sulfur-containg heterocycles can displace some ligands to form stable Pd-complexes. Thiophene- and furan-boronic acids are sensitive in polar reaction media and are easily degraded by protodeboronation.

In consequence, Suzuki coupling of heteroaryl derivatives is more challenging than aryl counterparts. Many efforts are carried out to develop efficient catalysis in heterocyclic series. A few examples have been described with Palladium complexes containing engineered and expensive ligands ${ }^{12-14}$. Recently, ligand-free systems have been reported using additive $^{15}$, colloidal nanoparticles in the presence of stabilizers $^{16}, \mathrm{Pd}(\mathrm{OAC})_{2}$ with a strong base ${ }^{17}$ or $\mathrm{Pd} / \mathrm{C}$ with an important catalytic loading. ${ }^{18}$

Aryl-heteroaryl derivatives are commonly present in natural compounds and exhibit a biological activity. Many applications have led to the discovery of drug or drug candidates. ${ }^{19,} 20$ The Suzuki reaction with heteroaryl substrates has been used at large-scales in the pharmaceutical industry. Illustrative examples are Gleevec (anticancer drug), PDE-4 inhibitor and

\footnotetext{
a. Bio-inspired Chemistry and Ecological Innovations (ChimEco) UMR 5021 CNRS University of Montpellier, Cap Delta, 1682 rue de la Valsière, 34790 Grabels, France; E-mail: claude.grison@cnrs.fr

b. LICSEN, NIMBE, CEA, CNRS, Université Paris-Saclay, CEA Saclay 91191 Gif-surYvette Cedex, France
}

AR-C123196 (treatment of asthma), Canagliflozin (type 2 diabetes), Ledipasvir (hepatitis C), or ABT-963 (inflammation and pain treatment). ${ }^{2,21}$

In a context of growing need for eco-friendly and sustainable processes in the pharmaceutical industries, an interesting challenge is to find green catalyst systems that efficiently catalyse the heteroSuzuki-Miyaura cross-coupling. Here, we wish to describe a green bio-based approach for this reaction.

As alternative to traditional catalysis, our group has recently introduced the concept of ecocatalysis ${ }^{22-24}$. This approach is based on the remarkable capacity of certain plants to hyperaccumulate transition metals in shoots or leaves. We have addressed the direct use of metals derived from contaminated plant waste as supported "Lewis acid" catalysts, oxidizing and reducing reagents in organic chemistry for the preparation of biomolecules. This was the first chemical recovery of new phytotechnologies. Recycling of waste from contaminated plants is the starting point of an unprecedented concept in chemistry, namely "ecocatalysis" ${ }^{25}$. The first results showed that ecocatalysts (called Eco-M) can be more efficient and selective than traditional catalysts. For example, Eco-Ni is 7.6 times more efficient than traditional $\mathrm{NiCl}_{2}$ for the synthesis of Monastrol, a potential anti-cancer agent ${ }^{26}$. The polymetallic systems obtained from the biomass are original (unusual oxidation states such as $\mathrm{Ni}(I I I)^{27}$, permitting new associations of chemical species ${ }^{23}$. They are also more efficient (in terms of chemo- and regio-selectivity ${ }^{28}$ than traditional catalysts in a number of reactions (multicomponent reactions, domino reactions, catalytic reduction ${ }^{29}$ and oxidation ${ }^{28,30,}$ ${ }^{31}$. They can be used as catalysts in synthetic transformations of biomass ${ }^{23}$, thus giving access to oligomers of biological interest $\left(5^{\prime}\right.$ capped DNA and RNA ${ }^{27}$, highly functionalized aromatic heterocyclic compounds, key intermediaries of varied industrial chemical processes $^{22}$ and biopesticides ${ }^{32}$.

This article is based on these pioneering results, revealing the high potential of catalysts derived from rhizofiltration, which consists in using aquatic plants capable of hyperaccumulating in their roots significant amounts of transition metals from aqueous solutions. ${ }^{33-}$

${ }^{35}$ Recently, we demonstrated that different plants such as Brassica juncea and Lolium multiflorum can extract and accumulate 
palladium which finally can be transformed in catalytic materials for Heck and Suzuki cross-coupling. ${ }^{36}$ EcoPd has revealed high activity without ligand and ideal microstructure ${ }^{36}$ (stable nanoparticles of 10-20 nm, stabilization of Pd on plant's mineral matrix. Moreover, EcoPd was successfully used for the coupling of aryl chlorides and areneboronic acids. However, EcoPd was difficult to recover and reuse, which could induce contamination of heteroaryl products. Moreover, the production of root biomass is limited by the nature of plants, the reactivity of EcoPd in heterocylic series is unknown and the reaction conditions must be improved in terms of green chemistry (solvent, reaction conditions, recycling and sustainability of sourcing).

In this article, we describe the use of Eichhornia crassipes (water hyacinth) to bioconcentrate $\mathrm{Pd}$ with the aim of increasing the root biomass and the capacity of EcoPd production, thereby allowing the scale-up and the study of EcoPd recycling-reusing in the delicate case of heterobiaryl compounds. Herein we report a novel bio-based EcoPd to perform hetero Suzuki coupling in green conditions. The preparation, characterization, reactivity and reusability of EcoPd, as well as Pd leaching, are described.

\section{Experimental}

\subsection{General}

All chemicals were purchased from Alfa Aesar, Carlo Erba or Sigma-Aldrich. Gas chromatography-mass spectrometry (GCMS) analyses were carried out by using a TRACE $^{\text {TM }} 1300$ apparatus equipped with an ISQ $^{\text {TM }}$ QD mass spectrometer detector (Thermo Fisher Scientific). The following chromatographic system was used for analytical experiments: GC-MS (Thermo TG-5SilMS, $20 \mathrm{~m}, 0.18 \mathrm{~mm}, 0.18 \mu \mathrm{m}$ ) with hydrogen as carrier gas $\left[80^{\circ} \mathrm{C}(0.5 \mathrm{~min})\right.$, followed by linear gradient from 80 to $280^{\circ} \mathrm{C}(5 \mathrm{~min})$ ] at a flow rate of 0.8 $\mathrm{mL} / \mathrm{min}$. Digestions were made by microwave assisted dissolution using a Multiwave GO microwave system (Anton Paar). In this procedure an exact mass (about $10 \mathrm{mg}$ ) was suspended into a Teflon reactor with a mixture of aq. $\mathrm{HCl}$ $37 \% /$ aq. $\mathrm{HNO}_{3} 65 \%(2: 4, \mathrm{v} / \mathrm{v}, 6 \mathrm{~mL})$. The reactors were heated according the following program: [rise in temperature from TA to $160^{\circ} \mathrm{C}(20 \mathrm{~min})$, followed by a stage at $\left.160^{\circ} \mathrm{C}(10 \mathrm{~min})\right]$. After cooling for $30 \mathrm{~min}$ the digests were transferred to $50 \mathrm{~mL}$ test tubes and diluted to $50 \mathrm{~mL}$ with aq. $1 \% \mathrm{HNO}_{3}$. Mineral compositions were determined by using a MP-AES 4200 (Agilent Technologies) equipped with a concentric nebulizer and a double pass cyclonic spray chamber. The pump speed during analysis was kept at $10 \mathrm{rpm}$ and the sample introduction tube diameter was $0.89 \mathrm{~mm}$. The analytical cycle consisted of $30 \mathrm{~s}$ rinsing with aq. $1 \%$ nitric acid followed by 25 $\mathrm{s}$ of sample uptake (pump speed $40 \mathrm{rpm}$ ) and then $20 \mathrm{~s}$ of equilibration before the reading at preselected integration times (pump speeds $10 \mathrm{rpm}$ ). The integration time was set to 3 $s$ for all elements. Unless otherwise stated the automatic background correction mode available in the software was used. An Agilent SPS-3 autosampler was used throughout the study. ${ }^{1} \mathrm{H}$ and ${ }^{13} \mathrm{C}$ NMR spectra were recorded on a Bruker DPX 300 spectrometer (Bruker). Chemical shifts are expressed in parts per million (ppm) from $\mathrm{CDCl}_{3}\left({ }^{1} \mathrm{H}=7.26,13 \mathrm{C}=77.16\right)$. $\mathrm{J}$ values are in $\mathrm{Hz}$. X-ray photoelectron spectroscopy (XPS) were performed on a Kratos Analytical Axis Ultra DLD, fitted with an Al $\mathrm{K} \alpha$ source monochromatised at $1486.6 \mathrm{eV}$. We used a hemispheric analyser working at pass energy of $50 \mathrm{eV}$ for the global spectrum and $20 \mathrm{eV}$ when focusing on the sole core levels. All products have been reported previously ${ }^{37-42}$, and their identities were confirmed by mass spectrometry, ${ }^{1} \mathrm{H}$ NMR and ${ }^{13} \mathrm{C}$ NMR spectroscopy. Bright-field TEM experiments were conducted on a Philips CM12 TEM operating at $120 \mathrm{kV}$. IR spectra were recorded on a PerkinElmer Spectrum 100 FT-IR spectrometer in ATR mode.

\subsection{Rhizofiltration experiments}

E. crassipes were purchased from a specialised grower (Nymphea company, France). The plants were placed in an outdoor tank filled with water to which guano was added as fertilizer.

\subsubsection{Rhizofiltration of effluents for the preparation of $\mathrm{EcoPd}_{1}$}

E. crassipes was exposed to a synthetic solution. An aqueous $\mathrm{HNO}_{3}$ solution of demineralised water $(1 \mathrm{~L}, \mathrm{pH}=2.5)$ containing $40 \mathrm{mg} / \mathrm{L}$ of $\mathrm{Pd}\left(\mathrm{NO}_{3}\right)_{2} \cdot 4 \mathrm{NH}_{3}(40 \mathrm{mg}, 134 \mu \mathrm{mol})$. The accumulation was carried out over 3 days with 1 plant/L of effluent with periodic mechanical homogenization of the solution.

\subsection{General procedure for the preparation of the EcoPd}

EcoPd was prepared from roots of $E$. crassipes (1 plant/L of effluent) after three days of rhizofiltration of aqueous media enriched with $\mathrm{Pd}(\mathrm{II})$ salts, with periodic mechanical homogenization of the solution. The collected roots were dried at $80^{\circ} \mathrm{C}$ for $6 \mathrm{~h}$. The obtained solid $(2.4 \mathrm{~g})$ was treated at $550^{\circ} \mathrm{C}$ for $6 \mathrm{~h}$ and the resulting ashes (144 mg) were added to $20 \mathrm{~mL}$ of concentrated $\mathrm{HCl}(37 \%)$. The suspension was stirred for $6 \mathrm{~h}$ at $90^{\circ} \mathrm{C}$. The reaction mixture was then filtered on a celite pad which was rinsed with boiling Milli-Q water $(10 \mathrm{~mL})$. The resulting brown solution, composed of different metal chloride salts, was concentrated under vacuum, yielding the ecocatalyst EcoPd as brown powder (202 mg). EcoPd was placed in an oven at $140^{\circ} \mathrm{C}$ for $12 \mathrm{~h}$ and then stored in a desiccator.

\subsection{General procedure for catalytic Suzuki cross-coupling reaction and analysis of reaction products}

The general procedure is described here in the case of 5-(2thienyl)indole ${ }^{39}$ including the recovery of black palladium.

2-Bromothiophene $(410 \mathrm{mg}, 2.5 \mathrm{mmol})$, indole-5-boronic acid (440 mg, $2.75 \mathrm{mmol}$ ), potassium carbonate $(410 \mathrm{mg}, 3 \mathrm{mmol}$ ) and $\operatorname{EcoPd}_{1}\left(2.3 \mathrm{mg}, 2.5 \mu \mathrm{mol}\right.$ of $\mathrm{Pd}, \mathrm{EcoPd}_{1}$ at $11.7 \mathrm{wt} \%$ of $\left.\mathrm{Pd}\right)$ were suspended into degassed glycerol $(5 \mathrm{~mL})$. The mixture was stirred at $120^{\circ} \mathrm{C}$ for $4 \mathrm{~h}$ in an oil bath under an argon atmosphere. The reaction was checked for completion by TLC (cyclohexane/AcOEt, 9:1, v/v) and GC-MS analysis after a short 
extraction of the organic material: $10 \mu \mathrm{L}$ of the crude were added into a $1 \mathrm{~mL}$ microtube containing a mixture of water and AcOEt (800 $\mu \mathrm{L}, 1: 1, \mathrm{v} / \mathrm{v})$. The microtube was vortexed before using organic layer to perform analysis. Deionised water $(50 \mathrm{~mL})$ and AcOEt $(50 \mathrm{~mL})$ were added into the flask and the mixture filtered through filtered glass to isolate black Pd for recycling. The organic layer was further washed by deionised water $(50 \mathrm{~mL} \times 3)$ before drying over $\mathrm{Na}_{2} \mathrm{SO}_{4}$. The organic layer was filtered and concentrated under vacuum. The residue was then purified by chromatography on a silica gel column (25 g) with a linear gradient of AcOEt (0-20\%) in cyclohexane as the mobile phase, giving the desired coupled compound as a yellow powder $(456 \mathrm{mg}, 2.30 \mathrm{mmol}$, yield 92\%). $\mathrm{R}_{f}=0.26$ (cyclohexane/AcOEt, 9:1, v/v). ${ }^{1} \mathrm{H}$ NMR (300 $\left.\mathrm{MHz}, \mathrm{CDCl}_{3}\right): \delta=8.05$ (br s, $\left.1 \mathrm{H}\right), 7.96-7.95(\mathrm{~m}, 1 \mathrm{H}), 7.55-7.52$ (dd, $\left.\mathrm{J}_{1}=8.5, \mathrm{~J}_{2}=1.9 \mathrm{~Hz}, 1 \mathrm{H}\right), 7.38-7.33(\mathrm{~m}, 2 \mathrm{~h}), 7.29-7.27$ (dd, J $=5.1,1 \mathrm{~Hz}, 1 \mathrm{H}), 7.20-7.18(\mathrm{~m}, 1 \mathrm{H}), 7.15-7.12\left(\mathrm{dd}, \mathrm{J}_{1}=5.0, \mathrm{~J}_{2}=\right.$ $3.6 \mathrm{~Hz}, 1 \mathrm{H}), 6.62-6.60(\mathrm{~m}, 1 \mathrm{H}) .{ }^{13} \mathrm{C} \mathrm{NMR}\left(75.5 \mathrm{MHz}, \mathrm{CDCl}_{3}\right): \delta=$ 103.0, 111.5, 118.3, 121.1, 122.1, 123.6, 125.2, 126.7, 128.0, 128.3, 135.5, 146.2. MS (EI): $\mathrm{m} / \mathrm{z}=199\left(\mathrm{M}^{+}, 100 \%\right), 171(13 \%)$, 154 (27\%), 127 (15\%), 99 (14\%) calcd for $\mathrm{C}_{12} \mathrm{H}_{9} \mathrm{NS}: 199.05$.

\section{Results and discussion}

\section{1 $\mathrm{EcoPd}_{1}$ Catalyst preparation and characterization}

\subsubsection{Rhizofiltration of $\mathrm{Pd}(\mathrm{II})$ rich effluents}

Previously our group studied the ability of Lolium multiflorum and Brassica juncea to accumulate in their roots $\mathrm{Pd}$ salts from aqueous media. ${ }^{36}$ We succeeded in reaching high Pd concentration in the root biomass after optimisation of the rhizofiltration conditions. These first results were very encouraging, but we quickly noticed the difficulty of implementing large-scale effluent rhizofiltration due to the biological characteristics and morphology of the plants studied, especially their low root biomass and low capacity for multiplication. Eichhornia crassipes is known ability to spread quickly, but also to accumulate efficiently within its roots high levels of transition metals ${ }^{43-45}$ including platinum group metals (PGM). ${ }^{43,46}$ With the goal of significantly improving the results obtained previously, we set up new experiments with Eichhornia crassipes. The experiments were carried out with high Pd concentration (40 $\mathrm{mg} / \mathrm{L}$ of $\left.\mathrm{Pd}\left(\mathrm{NH}_{3}\right)_{4}\left(\mathrm{NO}_{3}\right)_{2}\right)$. After 3 days of rhizofiltration, we analysed the palladium concentration in roots, floats and leaves of Eichhornia crassipes (Table 1). We also determined the bioconcentration factors (BCF: Pd concentration in roots, shoots or floats divided by $\mathrm{Pd}$ concentration in solution) and the translocation factors (TF: Pd concentration in shoots or floats divided by Pd concentration in roots) to identify the localisation of Pd salts in the plants. The results clearly indicate the high capacity of Eichhornia crassipes to bioconcentrate within its roots the palladium present in solution with a root BCF of 640 . The results also show that translocation to floats or leaves are negligible. This constitutes a major asset for the production of EcoPd in order to maximize the palladium concentration by exploiting the roots. The loadings obtained in a reproducible manner ( $0.9 \mathrm{wt} \%$ in roots) are of the same order of magnitude as those previously obtained with Lolium multiflorum or Brassica juncea (0.4-2.5 wt\% in roots) ${ }^{36,47}$ but with a much simpler and efficient implementation thanks to the significant root biomass of Eichhornia crassipes compared to Lolium multiflorum or Brassica juncea ( 1.8 g/plant versus $4-10 \mathrm{mg} /$ plant).

Table 1. Palladium concentration in roots and leaves of Eichhornia crassipes (wt\%, standard deviation). BCF and TF calculation.

\begin{tabular}{|c|c|}
\hline Starting $[\mathrm{Pd}]$ concentration in effluent $(\mathrm{mg} / \mathrm{L} \pm \mathrm{SD})$ & $13.9 \pm 0.12$ \\
\hline Roots concentration (wt $\% \pm \mathrm{SD}$ ) & $0.89 \pm 0.011$ \\
\hline BCF (in roots) & 640 \\
\hline Leaves concentration $(w t \% \pm S D)$ & $0.0010 \pm 0.00013$ \\
\hline BCF (in leaves) & 0.76 \\
\hline TF (leaves / roots) & 0.0011 \\
\hline Concentration in floats (wt $\% \pm \mathrm{SD}$ ) & $0.0006 \pm 0.00009$ \\
\hline BCF (in floats) & 0.45 \\
\hline TF (floats / roots) & 0.0007 \\
\hline
\end{tabular}

Figure 1. E. crassipes roots enriched with $\mathrm{Pd}(\mathrm{II})$ salts.

\subsubsection{Transformation of biomass into EcoPd}

Since no translocation was observed, roots were separated from the rest of the plant in order to prepare $\mathrm{EcoPd}_{1}$. Roots were first dried and then treated at $550^{\circ} \mathrm{C}$ to destroy most of the organic matter. The resulting ashes were treated with concentrated hydrochloric acid to convert the metal oxides formed during the heat treatment into chlorine salts. After filtration of the solution and evaporation to dryness, EcoPd ${ }_{1}$ is obtained as a brown powder.

\subsubsection{Mineral composition of $\mathrm{EcoPd}_{1}$}

The mineral composition of the $\mathrm{EcoPd}_{1}$ catalyst was determined via MP-AES analysis (Table 2). Pd is clearly the major transition metal in the ecocatalyst (11.7 wt\%). In addition of $\mathrm{Pd}$, the major physiological cations ( $\mathrm{Mg}, \mathrm{Fe}, \mathrm{Al}, \mathrm{Ca}$, $\mathrm{Na}$ and $\mathrm{K}$ ) were present because of the biosourced origin of the catalyst. A certain variability in the results, inherent to the use of biological material was observed. Consequently, the preparation of the ecocatalyst was repeated 10 times. The results given in Table 2 represent the average of these experiments.

Table 2. Mineral composition of $\mathrm{EcoPd}_{1}$ catalyst derived from Eichhornia crassipes ( $w t \% \pm$ standard deviation) determined by MP-AES analysis.

\begin{tabular}{llllllll}
\hline Element & $\mathbf{P d}$ & $\mathrm{Fe}$ & $\mathrm{Ca}$ & $\mathrm{K}$ & $\mathrm{Mg}$ & $\mathrm{Al}$ & $\mathrm{Na}$ \\
\hline Concentration & $\mathbf{1 1 . 7}$ & 0.4 & 9.3 & 7.1 & 1.0 & 0.3 & 2.5 \\
(wt\% \pm SD) & $\mathbf{0 . 1 9 0}$ & 0.005 & 0.160 & 0.048 & 0.006 & 0.002 & 0.025 \\
\hline
\end{tabular}




\subsubsection{X-Ray Photoelectron Spectroscopy analyses of EcoPd}

XPS of EcoPd $\mathrm{C}_{1}$ was performed allowing study the oxidation state of the Pd of EcoPd ${ }_{1}$ after the thermal treatment and the acid activation. The strong peak at $202 \mathrm{eV}$ corresponding to chlorine $2 p_{3 / 2}$ confirms the formation of chloride salts due to the aq. $\mathrm{HCl}$ treatment of the material (Figure 2). Highresolution analysis of $\mathrm{Pd}$ element was performed. The strong $\mathrm{Pd} 3 \mathrm{~d}_{5 / 2}$ peak at $338 \mathrm{eV}$ corresponds to $\mathrm{Pd}(\mathrm{II})$ as expected after the thermal treatment. $\mathrm{Pd}$ is expected to be present as $\mathrm{K}_{2} \mathrm{PdCl}_{4}$ according to literature data and our previous results ${ }^{36,48}$ Note the total absence PdO (peak at $337 \mathrm{eV}$ ) by comparison of our spectrum with the literature data ${ }^{49,50}$ demonstrating the effectiveness of the acid treatment on the ashes in transforming $\mathrm{PdO}$ into $\mathrm{K}_{2} \mathrm{PdCl}_{4}$.

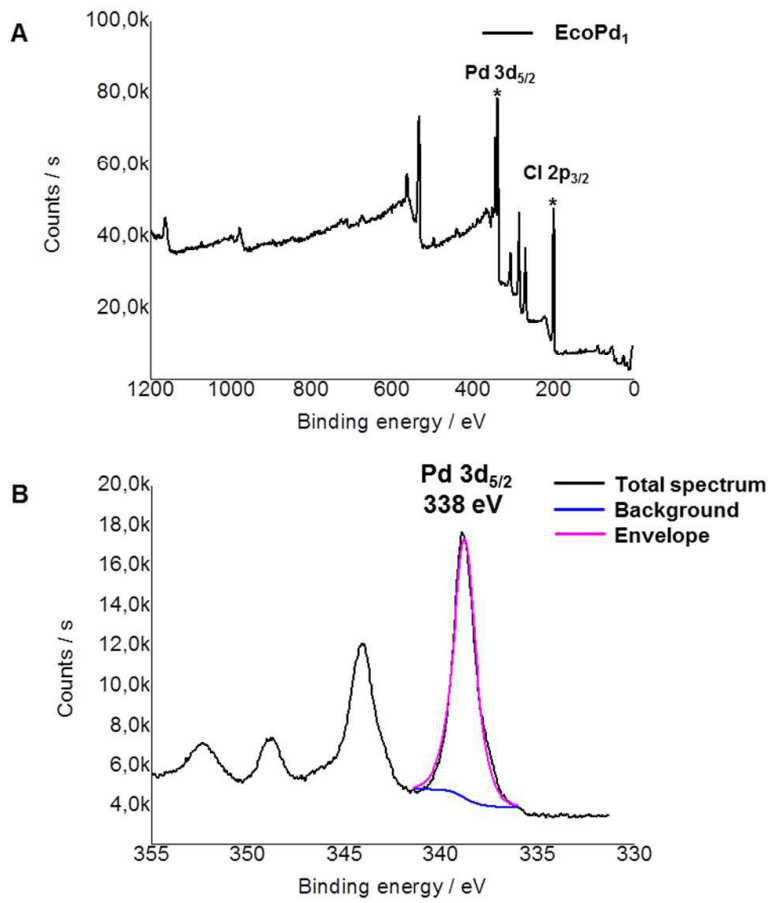

Figure 2. XPS analysis of $\mathrm{EcoPd}_{1}$. Survey spectrum showing the composition of the catalyst (A). High resolution spectrum of the Pd region showing the $P d 3 d_{5 / 2}$ peak at 338 eV assigned to $\mathrm{Pd}(\mathrm{II})(\mathrm{B})$.

\subsubsection{Transmission Electron Microscopy imaging}

EcoPd $_{1}$ was characterised by TEM imaging in bright field (BF) to achieve a better contrast for heavy elements (i.e., palladium versus other metals). We can observe that the palladium is present as clusters of spherical nanoparticles in the size range of 5-10 nm. The Pd nanoparticle (PdNPs) clusters are homogeneous in size, between 20 and $100 \mathrm{~nm}$ (Figure 3). Moreover, we can see clearly that the clusters are well dispersed on a matrix constituted by the other salt present in the catalyst. This saline matrix contributes significantly to the good dispersion of the clusters within the catalyst by preventing the formation of massive PdNPs aggregates. Here we notice a significant difference in morphology between the $\mathrm{EcoPd}_{1}$ obtained from Eichhornia crassipes and that previously described and obtained from Lolium multiflorum. ${ }^{36}$ Indeed, the latter exhibited smaller PdNPs of 3 to $4 \mathrm{~nm}$ that were extremely dispersed within the mineral matrix and did not exhibit cluster formation.
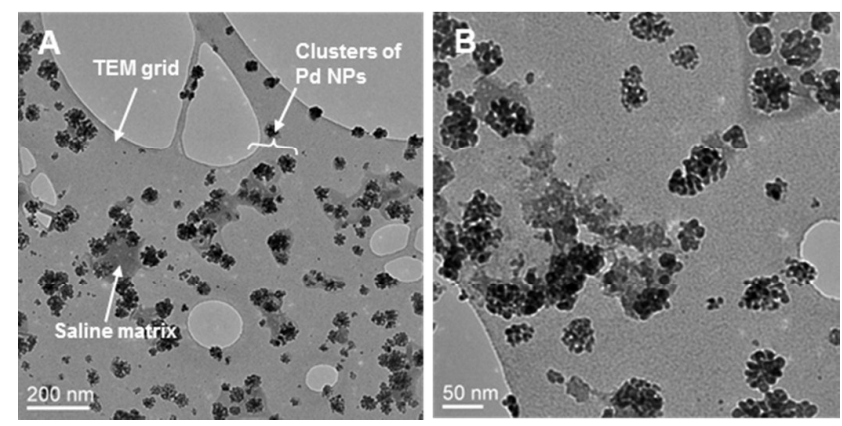
Figure 3. TEM imaging of EcoPd showing saline matrix on which are attached
PdNP clusters (in black, A). The average size of the PdNPs is in the size range 5-10 $\mathrm{nm}$ assembled as clusters of homogeneous size between 20 and $100 \mathrm{~nm}$ (B)

\subsubsection{Fourier Transform Infrared Analysis (FT-IR)}

The Pd complexation in Eichhornia crassipes roots was assessed by comparing the FT-IR analyses of the roots before and after rhizofiltration (respectively Figures $4 \mathrm{~A}$ and $\mathrm{B}$ ). The broad band at $3329 \mathrm{~cm}^{-1}$ of the native roots is indicative of the existence of bonded hydroxyl group. The band observed $1716 \mathrm{~cm}^{-1}$ can be assigned to the carboxyl group. In accordance with DellaGreca et al. ${ }^{51}$, we conclude that there are naphtyl carboxylic acid moieties. According to K. Mohanty et $a l^{52}{ }^{52}$, Dellagreca ${ }^{51}$, Wang et al. ${ }^{53}$, Shanab et al. $^{54}$ and Sarkar ${ }^{55}$, the band at $1632 \mathrm{~cm}^{-1}$ can be assigned to the $\mathrm{C}=\mathrm{C}$ bond. The spectrum of the Pd-loaded (figure $4 \mathrm{~B}$ ) root was compared with that of native root. A significant shift of absorption band can be observed indicating several interactions between adsorbed palladium and root. A significant shift of the broad absorption peak of $3329 \mathrm{~cm}^{-1}$ to $3299 \mathrm{~cm}^{-1}$ reflects $\mathrm{Pd}$ binding to the $\mathrm{OH}$ group. The band at $1716 \mathrm{~cm}^{-1}$ disappeared after rhizofiltration, indicating that the carboxyl group also contributed to the formation of a complex with $\mathrm{Pd}^{2+}$. Finally, the peak at 1632 $\mathrm{cm}-1$ has been shifted to $1590 \mathrm{~cm}^{-1}$, and may be due to the complexation of $\mathrm{Pd}^{2+}$. These results indicated that strong chelation occurs between $\mathrm{Pd}^{2+}$ and the roots of $E$. crassipes.

The same analysis was repeated on roots leading to $\mathrm{EcoPd}_{2}$ after recycling of $\mathrm{EcoPd}_{1}$. The results obtained are comparable demonstrating the consistency of the root morphology (see S1 and S2, ESI) 

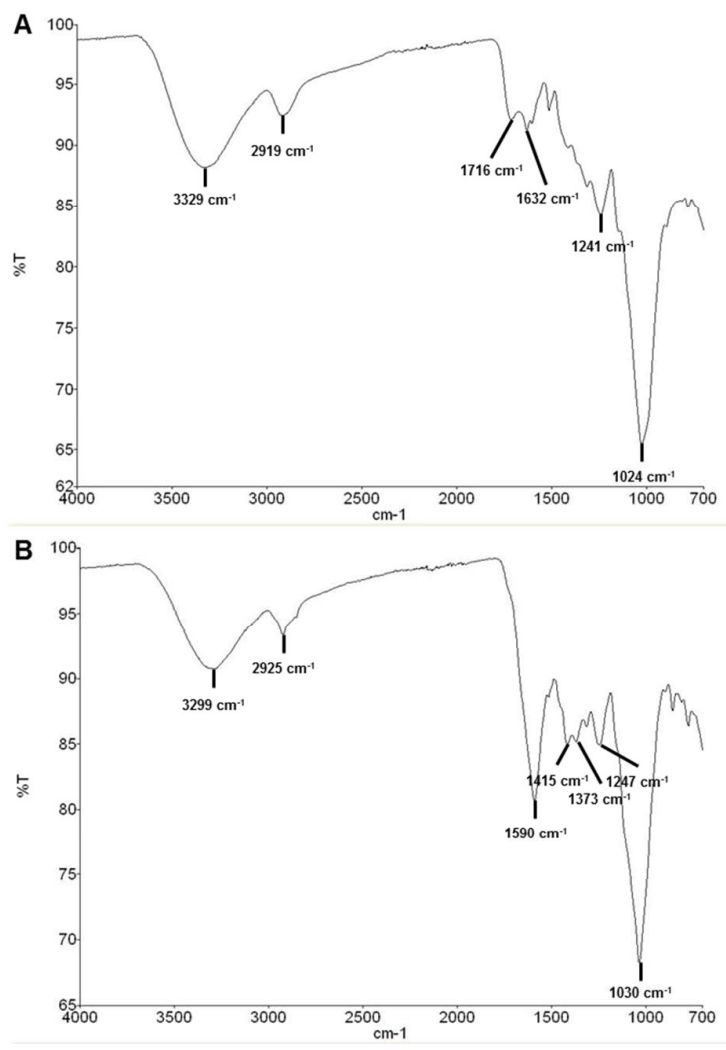

Figure 4. FT-IR spectrum of unused roots (A) and Pd loaded roots (B).

\subsection{Suzuki cross-coupling of heteroaryl substrats}

The common bases used for Suzuki coupling are $\mathrm{Cs}_{2} \mathrm{CO}_{3}, \mathrm{~K}_{2} \mathrm{CO}_{3}$, $\mathrm{Na}_{3} \mathrm{PO}_{4}, \mathrm{NaOMe}, \mathrm{KF}$ and $\mathrm{NaOH} .{ }^{56}$ Among these $\mathrm{K}_{2} \mathrm{CO}_{3}$ is cheap, abundant, environmentally friendly ${ }^{57,58}$ and non-toxic ${ }^{59,60}$ making it an obvious choice for this study.

The solvent is a crucial element of Suzuki reaction. With the first generation of EcoPd, the best results were obtained in toluene. ${ }^{29}$ In the present study, much effort was applied to conform to the criteria of Green Chemistry.

Table 3 summarises the results obtained with different solvents whith $\mathrm{K}_{2} \mathrm{CO}_{3}$ and $0.1 \mathrm{~mol} \%$ of $\mathrm{Pd}$ in $\mathrm{EcoPd}_{1}$ without ligand or additive. We chose as model substrates 2bromothiophene and phenylboronic acid. The best results were obtained with glycerol (Table 3, entry 1 ) which has for several years been considered a promising bio-sourced green solvents ${ }^{61,62}$ and has been used with success for many organic reactions such as hydrogen transfer, ${ }^{63,64}$ CuAAC, ${ }^{65}$ PausonKhand carbocyclisations ${ }^{66}$ and $\mathrm{Pd}$ catalyzed cross-coupling reactions. ${ }^{67,68}$
Table 3. Study of the influence of the solvent.

\begin{tabular}{|c|c|c|}
\hline & & 3a \\
\hline Entry & Solvent & Conversion $(\%)^{a, b}$ \\
\hline 1 & Glycerol & $89 \%$ \\
\hline 2 & DMF & $80 \%$ \\
\hline 3 & IPA & $79 \%$ \\
\hline 4 & MeTHF & $79 \%$ \\
\hline 5 & Toluene & $68 \%$ \\
\hline 6 & $\mathrm{MeCN}$ & $59 \%$ \\
\hline 7 & CPME & $40 \%$ \\
\hline 8 & $\mathrm{BuOH}$ & $44 \%$ \\
\hline \multicolumn{3}{|c|}{$\begin{array}{l}{ }^{a} \text { Reaction conditions: } 250 \mu \mathrm{mol} 1 \mathrm{a}, 275 \mu \mathrm{mol} 2 \mathrm{a}, 300 \mu \mathrm{mol} \mathrm{K}{ }_{2} \mathrm{CO}_{3}, 0.1 \mathrm{~mol} \% \mathrm{Pd} \\
\text { (EcoPd1), } 100^{\circ} \mathrm{C}, 500 \mu \mathrm{L} \text { solvent, } 4 \mathrm{~h} \text {. } \\
{ }^{b} \text { Conversions reported were determined by GC-MS after calibration with dodecane as } \\
\text { internal standard. }\end{array}$} \\
\hline
\end{tabular}

The Pd catalyst loading is another key parameter of crosscoupling reaction. This aspect has been finely studied with 2bromothiophene and phenylboronic acid (Table 4). A quantitative yield was obtained in less than one hour with 1 mol\% of Pd (Table 4, entry 1 ). By decreasing the catalytic charge to $0.1 \mathrm{~mol} \%$, a quantitative conversion was observed with a reasonable reaction time of 4 hours (Table 4 , entry 2 ). With $0.01 \mathrm{~mol} \%$ of $\mathrm{Pd}$, the reaction was significantly advanced after 4 hours (Table 4, entry 3 ). However, the yield did not reach complete conversion even after prolonged reaction time. This behaviour is probably due to the deactivation of the catalyst under the sponge-like form of Pd black, observed in suspension at the end of the reaction. Indeed its formation is favoured by the reducing properties of glycerol. ${ }^{69,70}$ Finally, the reaction could be performed with a catalyst loading as low as $0.001 \mathrm{~mol} \%$ (Table 4 , entries 4 and 5 ). When the reaction time is extended to $40 \mathrm{~h}$, an interesting turnover number (TON) of 92000 was achieved. This result indicated that $\mathrm{EcoPd}_{1}$ has a very good stability at very low concentration. This observation may be rationalized by de Vries works, which are established the direct correlation between palladium nanoparticle stability and the concentration of palladium in solution. $^{71}$ 


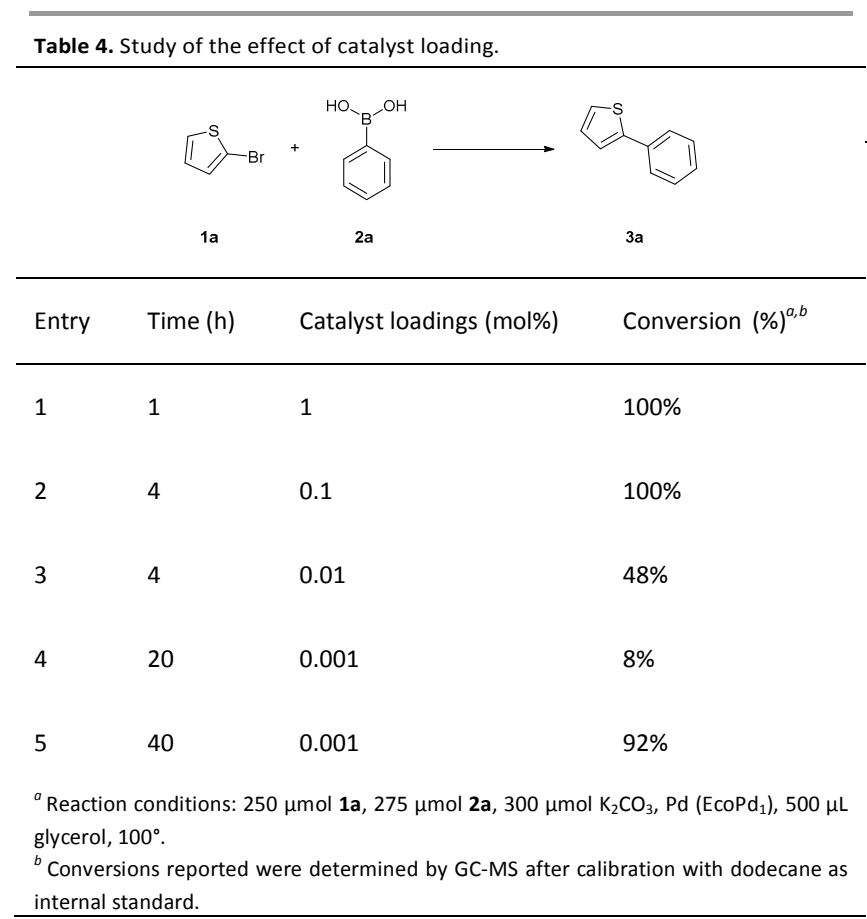

Thereafter, we determined the influence of the temperature (Table 5) with the model reaction using 2-bromothiophene and phenylboronic acid. Glycerol is a sustainable solvent for green chemistry. However, it is highly viscous at normal conditions of temperature and pressure making it difficult to use at low temperatures. Its viscosity dramatically decreases at temperatures above $60^{\circ} \mathrm{C}^{72}$ which was the minimum temperature of this study. The results showed there is a clear gap concerning the reaction efficiency between 80 and $100^{\circ} \mathrm{C}$ (yield increasing from 59 to $84 \%$ ) and we observed that the reaction was quantitative for higher temperature $\left(120^{\circ} \mathrm{C}\right)$. This temperature was used for this study.
${ }^{a}$ Reaction conditions: $250 \mu \mathrm{mol}$ 1a, $275 \mu \mathrm{mol} 2 \mathrm{a}, 300 \mu \mathrm{mol} \mathrm{K}_{2} \mathrm{CO}_{3}, 0.1 \mathrm{~mol} \% \mathrm{Pd}$ $\left(\mathrm{EcoPd}_{1}\right), 500 \mu \mathrm{L}$ glycerol, $2 \mathrm{~h}$.

${ }^{b}$ Conversions reported were determined by GC-MS after calibration with dodecane as internal standard.

Subsequently we investigated the scope of $\mathrm{EcoPd}_{1} /$ glycerol system for the heteroaryl Suzuki reactions under optimised conditions (i.e. $0.1 \mathrm{~mol} \%$ of $\mathrm{Pd}$ at $120^{\circ} \mathrm{C}$ in glycerol). A survey of heteroaryl bromide cross-coupling with phenylboronic acid is provided in table 6 . Interesting results were achieved with different substrates. The coupling of 2-bromothiophene and 3bromopyridine gave yield of $97 \%$ in a few minutes (Table 6 , entry 1 and 3). The reaction was quantitative after 1 hour. Electron-poor heteroaryl bromides such as 3-bromopyridine could couple efficiently with phenylboronic acid (Table 6, entry 6). For comparison, the catalytic ability for catalyzing coupling reactions of chloride and iodide-derivatives should be conducted. In the cases of 2-iodothiophene (entries 4 and 5) and 3-iodoprydine (entry 8), the Pd loading catalyst can be reduced, but the reaction was slower. Unfortunately, the reaction cannot be extended to chloroaryl derivatives. The use of 1-chloro-4-nitrobenzene or 4-chlorobenzonitrile led to the deboronylation of the arylboronic acid. ${ }^{73}$

As expected, the $\mathrm{NH}$ group deactivated $\mathrm{EcoPd}_{1} \cdot{ }^{12}$ The coupling of 4-bromopyrazole is not possible, even with prolonged reaction time (Table 6, entry 9 ). $\mathrm{N}$-Protected pyrazole reacted in satisfactory yield (Table 6 , entry 10 ).

Table 6. Suzuki cross-coupling of boronic acids with heteroaryl bromides.

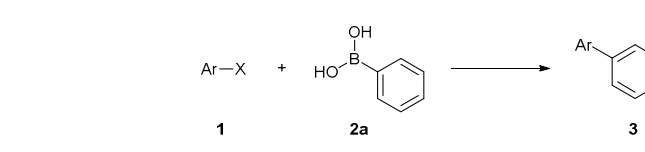

$\begin{array}{lll}\text { Entry } & \begin{array}{l}\text { Heteroaryl } \\ \text { halide }\end{array} & \text { Product }\end{array} \quad$ Time (h) Conversion(\%) ${ }^{\mathrm{a}, \mathrm{b}}$

Table 5. Study of the effect of the temperature.

$$
\widehat{N}_{\mathrm{Sr}}^{\mathrm{Br}}
$$

$3 a$

0.15

97
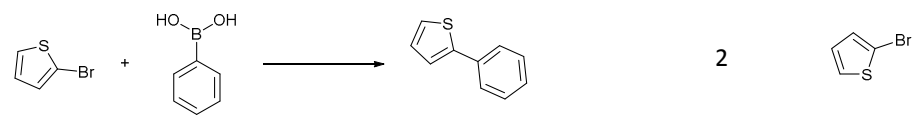

$3 a$

1

$>99(88)$

1a

$3 a$

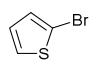

$3 a$

$4^{c}$

62

\begin{tabular}{ll}
\hline Entry & Temperature $\left({ }^{\circ} \mathrm{C}\right) \quad$ Conversion $(\%)^{a, b}$ \\
\hline
\end{tabular}

60

$32 \%$

2

80

$59 \%$<smiles>Ic1cccs1</smiles>

$3 a$

$4^{c}$

77

5<smiles>Ic1cccs1</smiles>

$3 a$

$16^{c}$

$>99$

3

100

$84 \%$

6

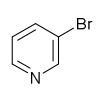

$3 b$ 


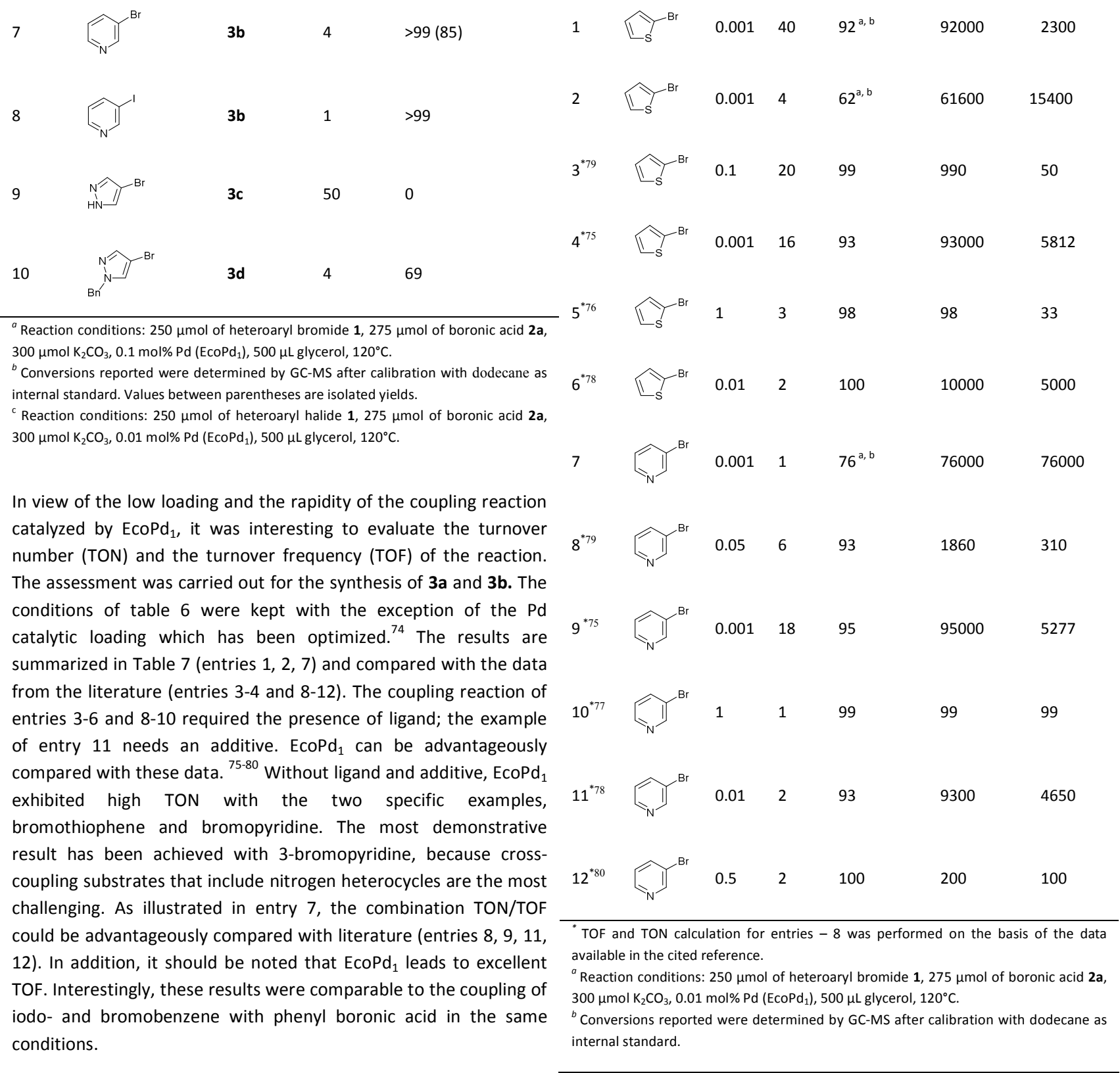

This demonstrates the higher stability of EcoPd compared to conventional Pd catalysts, which are associated with a ligand or an additive.

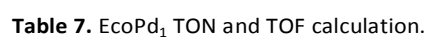

\begin{tabular}{llllll}
\hline Entry HetAr \\
Mol\%
\end{tabular}

Thereafter, the coupling of different heteroaryl boronic acids with bromobenzene was examined in order to determine the effect of the nature of the heteroatom-bearing partner on the efficiency of $\mathrm{EcoPd}_{1}$. From a mechanistic viewpoint, the boronic acid plays the role of nucleophile in the Suzuki coupling. ${ }^{81}$ Thus, the presence of a heteroatom can notably influence the coupling efficiency. While good results were obtained when the heteroatom was carried by the haloaryl $\mathbf{1}$, the performance of $\mathrm{EcoPd}_{1}$ was less general with a hetero boronic acid derivative $\mathbf{2}$ (Table 6). Indole-5-boronic acid led to significant conversion in $4 \mathrm{~h}$ (Table 8 , entry 1 ). Unfortunately, thiophene and pyridine boronic acids gave poor results with bromobenzene. 
Table 9. Suzuki cross-coupling of various aryl and heteroarylboronic acids with 2bromothiophene.

Table 8. Suzuki cross-coupling of heteroarylboronic acids with bromobenzene.

3b
3

Heteroaryl-substituted thiophene moieties are common in drug candidates ${ }^{82-84}$ and polythiophenes possess very interesting optoelectronic properties making them extremely useful and efficient in the fields of conducting materials and as a photosensitizer for photovoltaic cells. ${ }^{85-87}$ Suzuki coupling is widely used for the synthesis of such material. Thus, we investigated the coupling of 2-bromothiophene with different partners (Table 9), including heteroboronic acid partners. By using the conditions presented above, we managed to couple different boronic acid derivatives bearing either electron donating (EDG) or electron-withdrawing groups (EWG). Total conversions were observed in a reasonable time of $4 \mathrm{~h}$ with activated substrate bearing EWG (Table 8, entries 6 and 7), and with indole-5-boronic acid despite the presence of the additional heteroatom (Table 9, entry 5). Good yield was also obtained in $4 \mathrm{~h}$ with boronic acid bearing EDG (Table 9, entry 1). The successful coupling with 2-thienylboronic acid (Table 9, entry 4) could open the way to the synthesis of polythiophene.

Entry




\subsection{Recycling of EcoPd ${ }_{1}$ : catalyst preparation from post-reaction} solution

The major problem of homogeneous catalysts, with or without ligand, is the difficulty of recover and reuse the residual $\mathrm{Pd}$ metal in the synthesized product. Because of the high value of palladium several research groups developed their own recycling method using materials derived from chitosan ${ }^{89-91}$, ion exchange resin ${ }^{92}$, magnetic nanoparticles ${ }^{93}$ or thiolfunctionalized zirconium oxide MOFs. ${ }^{94}$ In the last part of this work, we demonstrate that the palladium can be recycled from the reaction crude by an ecological and efficient methodology. It is based on the following principle: the postreaction solution of a transformation catalysed by an EcoPd $\left(\mathrm{EcoPd}_{1}\right)$ can be treated by rhizofiltration and a new, active EcoPd $\left(\mathrm{EcoPd}_{2}\right)$ can be regenerated.

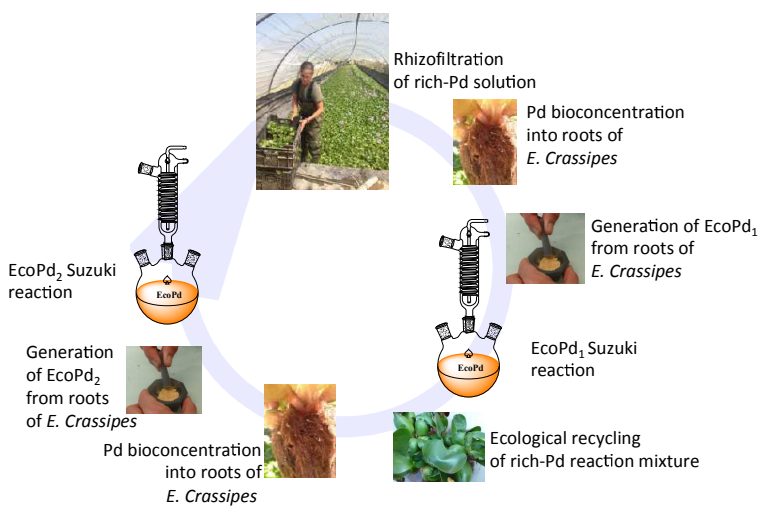

Scheme 1. Process of ecological recycling of EcoPd illustrated by the Suzuky reaction.

The preparation of $\mathbf{3 a}$ was used as study model. The study was carried out on large scale $(20.4 \mathrm{~g}, 125 \mathrm{mmol}$ of 2bromothiophene) in order to use a significant amount of $\operatorname{EcoPd}_{1}(111 \mathrm{mg}$ of EcoPd $1,13.3 \mathrm{mg}$ of Pd, $125 \mu \mathrm{mol}$ of $\mathrm{Pd})$ and enable the recycling process (see S1, ESI). The amount of any Pd leached was analysed in each layer by MP-AES (Microwave Plasma-Atomic Emission Spectrometer). No Pd was detected either into organic or aqueous layer after crude workup (Table 10). Note the high $\mathrm{K}$ concentration due to the use of $\mathrm{K}_{2} \mathrm{CO}_{3}$ as base for the coupling reaction (Aq. layer from crude, Table 10).

We can hypothesize that the quantitative formation of black palladium at the end of the reaction is an opportunity to avoid Pd leaching and to facilitate recycling. In order to confirm this explanation, we analysed the crude product 3 a by MP-AES. No Pd was detected.
Table 10. Mineral composition of solid samples and solutions involved in the recycling of palladium determined by MP-AES analysis (wt\% for solid sample, $\mathrm{mg} / \mathrm{L}$ for liquid sample).

\begin{tabular}{lllllllll}
\hline $\begin{array}{l}\text { Liquid sample } \\
\text { (mg/L) }\end{array}$ & $\mathbf{P d}$ & $\mathrm{Fe}$ & $\mathrm{Ca}$ & $\mathrm{K}$ & $\mathrm{Mg}$ & $\mathrm{Al}$ & $\mathrm{Na}$ \\
$\begin{array}{c}\text { Aq. layer from } \\
\text { crude }\end{array}$ & $\mathbf{0}$ & 1.2 & 15.3 & 3361.8 & 1.3 & 0 & 12.8 \\
$\begin{array}{c}\text { Org. layer from } \\
\text { crude }\end{array}$ & $\mathbf{0}$ & 0 & 6.1 & 4.1 & 0 & 0 & 3.49 \\
$\begin{array}{l}\text { Effluent before } \\
\text { rhizofiltration }\end{array}$ & $\mathbf{1 3 . 2}$ & 0 & 16.0 & 5.4 & 1.15 & 0 & 4.3 \\
$\begin{array}{l}\text { Effluent } \\
\text { rhizofiltration }\end{array}$ & $\mathbf{3 . 0 8}$ & 2.6 & 47.5 & 60.3 & 17.9 & 1.29 & 30.0 \\
$\begin{array}{l}\text { Solid sample (wt\%) } \\
\text { Roots }\end{array}$ & $\mathbf{P d}$ & $\mathrm{Fe}$ & $\mathrm{Ca}$ & $\mathrm{K}$ & $\mathrm{Mg}$ & $\mathrm{Al}$ & $\mathrm{Na}$ \\
$\begin{array}{l}\text { EcoPd } \\
2\end{array}$ & $\mathbf{0 . 8 1}$ & 0.04 & 0.07 & 0.12 & 0.03 & 0.01 & 0.06 \\
\end{tabular}

The post-synthesis solution was treated in three successive steps: a) the recovery of the black Pd by simple filtration; b) the dissolution of the latter in a minimum of aqua regia; (c) its dilution with water. These three steps allowed quantitative recovery of the $\mathrm{Pd}$ engaged in the synthesis in the form of an effluent, which can be subjected directly to rhizofiltration (Table 10, solution before rhizofiltration analysis, see details in S2, ESI). The procedure allowed the recovery of $77 \%$ of the Pd by Eichhornia crassipes. A second rhizofiltration allowed the recovery of the remaining $\mathrm{Pd}$ (see details in S3 and S4, ESI). The EcoPd $\mathrm{P}_{2}$ obtained after roots treatment contained $11.1 \mathrm{wt} \%$ of Pd. This concentration was very close to $\operatorname{EcoPd}_{1}(11.7$ wt\%).

\subsection{Reuse of EcoPd and catalytic activity}

EcoPd $d_{2}$ was successfully used for a Suzuki coupling reaction. The preparation of $\mathbf{3 a}$ led to the same result. The $\mathrm{EcoPd}_{2}$ catalytic activity is totally maintained. A further recycling cycle of the palladium from $\mathrm{EcoPd}_{2}$ was carried out by adjusting the amount of water used during the aqua regia dilution step in order to maintain a $\mathrm{Pd}$ concentration of $13 \mathrm{mg} / \mathrm{L}$ leading to $\mathrm{EcoPd}_{3}$ (Table 11). By doing this concentration adjustment, the successive EcoPd concentration remained of the same order of magnitude ( 11-14 wt\% of Pd) demonstrating the reproducibility and the recycling process that contributes to making this model system "eco-friendly".

Table 11. Mineral composition of $\mathrm{EcoPd}_{3}$ catalyst derived from Eichhornia crassipes (wt $\% \pm$ standard deviation) determined by MP-AES analysis.

\begin{tabular}{llllllll}
\hline Element & $\mathbf{P d}$ & $\mathrm{Fe}$ & $\mathrm{Ca}$ & $\mathrm{K}$ & $\mathrm{Mg}$ & $\mathrm{Al}$ & $\mathrm{Na}$ \\
\hline Concentration & $\mathbf{1 4 . 4}$ & 2.2 & 5.8 & 2.2 & 1,3 & 1.8 & 0.4 \\
(wt\% $\pm \mathrm{SD}$ ) & $\mathbf{0 . 0 1 4}$ & 0.040 & 0,031 & 0,002 & 0,008 & 0,007 & 0,001
\end{tabular}

As summarized in Table 12, the EcoPd could be used for up to four cycles, without decreasing of catalytic activity. These results demonstrate the reusability of EcoPd in the Suzuki reaction. 
Table 12. Reusability of EcoPd in the coupling of 2-bromothiophene and phenylboronic acid in our optimised conditions.

\begin{tabular}{ll}
\hline EcoPd & Conversion(\%) \\
\hline EcoPd $_{1}$ & $>99$ \\
$\mathrm{EcoPd}_{2}$ & $>99$ \\
$\mathrm{EcoPd}_{3}$ & $>99$ \\
$\mathrm{EcoPd}_{4}$ & $>99$
\end{tabular}

$\mathrm{EcoPd}_{4}>99$

${ }^{a}$ Reaction conditions: $250 \overline{\mu \mathrm{mol} 1 \mathrm{a}, 275 \mu \mathrm{mol} 2 \mathrm{a}, 300 \mu \mathrm{mol} \mathrm{K}}{ }_{2} \mathrm{CO}_{3}, 0.1 \mathrm{~mol} \% \mathrm{Pd}(\mathrm{EcoPd})$ $500 \mu \mathrm{L}$ glycerol, $2 \mathrm{~h}$

${ }^{b}$ Conversions reported were determined by GC-MS after calibration with dodecane as internal standard.

The efficiency of ecological recycling based on rhizofiltration can be advantageously compared to direct using of black Pd. Whereas the sequence rhizofiltration/ecocatalysis led to excellent results (Table 12), black Pd exhibit a negligible catalytic activity in the same conditions (only $1 \%$ of $\mathbf{3}$ a was detected).

\section{Conclusion}

In conclusion, we have developed a biobased and green procedure for the Suzuki-Miyaura cross-coupling of heteroaryl bromides and heteroboronic acids. We have demonstrated the utility of Eichhornia crassipes to prepare efficient and recyclable EcoPd. This ecocatalyst was fully characterized and then exploited with success in the Suzuki coupling of various heterocyclic reagents under homogenous conditions compatible with green chemistry and without ligands or additives. Moreover, we developed an eco-friendly and effective recycling process of the homogeneous $\mathrm{Pd}$ catalyst that can be repeated without loss of activity of the catalyst. Finally, this knowledge should prove useful of the ecocatalysis in green catalysis. The methodology opens the opportunity for the large-scale synthesis of industrial targets at the frontiers of sustainable processes and phytotechnologies.

\section{Acknowledgements}

This work was supported by the Centre National de la Recherche Scientifique (CNRS). The authors thank Eddy Petit for NMR analyses of isolated products and Dr. Nathalie Fresneau for TEM images.

\section{References}

1. L. Yin and J. Liebscher, Chem. Rev., 2007, 107, 133-173.

2 2. P. G. Gildner and T. J. Colacot, Organometallics, 2015, 34, 5497-5508.

3 3. P. Ruiz-Castillo and S. L. Buchwald, Chem. Rev., 2016, 116, 12564-12649.

4 4. A. Fihri, M. Bouhrara, B. Nekoueishahraki, J. M. Basset and V. Polshettiwar, Chem. Soc. Rev., 2011, 40, 5181-5203.
7

8

5. M. Mondal and U. Bora, Green Chem., 2012, 14, 1873-1876.

6. G. K. Rao, A. Kumar, S. Kumar, U. B. Dupare and A. K. Singh, Organometallics, 2013, 32, 2452-2458.

7. F. S. Han, Chem. Soc. Rev., 2013, 42, 5270-5298.

8. Q. Zhang, H. Su, J. Luo and Y. Wei, Catal. Sci. Technol., 2013, 3, 235-243.

99 9. J. Yang, D. Wang, W. Liu, X. Zhang, F. Bian and W. Yu, Green Chem., 2013, 15, 3429-3437.

10 10. C. Deraedt and D. Astruc, Acc. Chem. Res., 2013, 47, 494-503.

11. C. Peter, A. Derible, J.-M. Becht, J. Kiener, C. Le Drian, J. Parmentier, V. Fierro, M. Girleanu and $\mathrm{O}$. Ersen, Journal of Materials Chemistry A, 2015, 3, 12297-12306

12. N. Kudo, M. Perseghini and G. C. Fu, Angew. Chem. Int. Ed., 2006, 45, 1282-1284.

13. G. K. Rao, A. Kumar, J. Ahmed and A. K. Singh, Chem. Commun., 2010, 46, 5954-5956.

14. K. L. Billingsley, K. W. Anderson and S. L. Buchwald, Angew. Chem. Int. Ed., 2006, 118, 35643568.

15. C. Liu, Q. Ni, P. Hu and J. Qiu, Org. Biomol. Chem., 2011, 9, 1054-1060.

16 16. Y. Li and M. A. El-Sayed, J. Phys. Chem. B, 2001, 105, 8938-8943.

1717 J. S. Siddle, A. S. Batsanov and M. R. Bryce, Eur. J. Org. Chem., 2008, 2008, 2746-2750.

18 18. Y. Kitamura, S. Sako, A. Tsutsui, Y. Monguchi, T. Maegawa, Y. Kitade and H. Sajiki, Adv. Synth. Catal., 2010, 352, 718-730. 19. J. S. Carey, D. Laffan, C. Thomson and M. T. Williams, Org. Biomol. Chem., 2006, 4, 2337-2347.

20. S. D. Roughley and A. M. Jordan, J. Med. Chem. 2011, 54, 3451-3479. V. L. Budarin, P. S. Shuttleworth, J. H. Clark and R. Luque, Curr. Org. Synth., 2010, 7, 614-627.

22. V. Escande, L. Garoux, C. Grison, Y. Thillier, F. Debart, J.-J. Vasseur, C. Boulanger and C. Grison, Appl. Catal., B, 2014, 146, 279-288. 23. V. Escande, T. K. Olszewski, E. Petit and C. Grison ChemSusChem, 2014, 7, 1915-1923.

24. G. Clavé, C. Garel, C. Poullain, B.-L. Renard, T. K. Olszewski, B. Lange, M. Shutcha, M.-P. Faucon and C. Grison, RSC Adv., 2016, 6, 59550-59564. 25. C. Grison, Environ. Sci. Pollut. Res. Int., 2015, 22, 5589-5591.

26. C. Grison, V. Escande, E. Petit, L. Garoux, C. Boulanger and C. Grison, RSC Adv., 2013, 3, 22340.

27. Y. Thillier, G. Losfeld, V. Escande, C. Dupouy, J.-J. Vasseur, F. Debart and C. Grison, RSC Adv., 2013, 3, 5204-5212.

28. V. Escande, C. H. Lam, C. Grison and P. T. Anastas, ACS Sustainable Chem. Eng., 2017, 5, 3214-3222.

29. V. Escande, A. Velati, C. Garel, B.-L. Renard, E. Petit and C. Grison, Green Chem., 2015, 17, 2188-2199. 
30. V. Escande, B. L. Renard and C. Grison, Environ. Sci. Pollut. Res. Int., 2015, 22, 5633-5652.

31. V. Escande, E. Petit, L. Garoux, C. Boulanger and C. Grison, ACS Sustainable Chem. Eng., 2015, 3, 27042715.

32. V. Escande, A. Velati and C. Grison, Environ. Sci. Pollut. Res. Int., 2014, 22, 5677-5685.

33. M. I. Lone, Z.-I. He, P. J. Stoffella and X.-e. Yang, J. Zhejiang. Univ. Sci. B, 2008, 9, 210-220.

34. M. Naaz, A. Dutta, S. Kumari and S. Farooqui, Res. Rev. : J. Ecol., 2013, 2, 1-9.

35. S. Rezania, M. Ponraj, A. Talaiekhozani, S. E. Mohamad, M. F. Md Din, S. M. Taib, F. Sabbagh and F. M. Sairan, J. Environ. Manage., 2015, 163, 125-133.

36. C. Garel, B.-L. Renard, V. Escande, A. Galtayries, P. Hesemann and C. Grison, Appl. Catal., A, 2015, 504, 272-286.

37. A. S. Demir, Ö. Reis and M. Emrullahoğlu, Tetrahedron, 2002, 58, 8055-8058.

38. S. D. Walker, T. E. Barder, J. R. Martinelli and S. L. Buchwald, Angew. Chem. Int. Ed., 2004, 43, 1871-1876. 39. J. Yang, S. Liu, J.-F. Zheng and J. Zhou, Eur. J. Org Chem., 2012, 2012, 6248-6259.

40. M. E. Budén, J. F. Guastavino and R. A. Rossi, Org. Lett., 2013, 15, 1174-1177.

41. V. P. Reddy, R. Qiu, T. Iwasaki and N. Kambe, Org. Lett., 2013, 15, 1290-1293.

42. Y. Zou, G. Yue, J. Xu and J. S. Zhou, Eur. J. Org. Chem., 2014, 2014, 5901-5905.

43. M. E. Farago and P. J. Parsons, Environ. Technol. Lett., 1985, 6, 165-174.

44. F. O. Agunbiade, B. I. Olu-Owolabi and K. O Adebowale, Bioresour. Technol., 2009, 100, 4521-4526. 45. A. P. Vitória, F. Lage-Pinto, L. B. Campaneli, M. G. Almeida, C. M. M. Souza, C. E. Rezende, R. A. Azevedo and J. G. Oliveira, Braz. J. Plant Physiol., 2010, 22, 4959.

46. M. E. Farago and P. J. Parsons, Chem. Speciation Bioavailability, 1994, 6, 1-12.

47. B. A. Lesniewska, J. Messerschmidt, N. Jakubowski and A. Hulanicki, Sci. Total. Environ., 2004, 322, 95-108. 48. G. Kumar, J. Blackburn, R. Albridge, W. Moddeman and M. Jones, Inorg. Chem., 1972, 11, 296300.

49. K. Noack, H. Zbinden and R. Schlögl, Catal. Lett., 1990, 4, 145-155.

50. M. Brun, A. Berthet and J. Bertolini, J. Electron. Spectrosc. Relat. Phenom., 1999, 104, 55-60.

51. M. DellaGreca, L. Previtera and A. Zarrelli, Tetrahedron, 2009, 65, 8206-8208.

52. K. Mohanty, M. Jha, B. C. Meikap and M. N. Biswas, Chem. Eng. J., 2006, 117, 71-77.

53. M. Z. Wang, X. H. Cai and X. D. Luo, Helv. Chim. 79 Acta, 2011, 94, 61-66.

54. S. M. Shanab, E. A. Shalaby, D. A. Lightfoot and H. 80 A. El-Shemy, Plos One, 2010, 5, e13200.
55. M. Sarkar, A. K. M. L. Rahman and N. C. Bhoumik, Water Resour. Ind., 2017, 17, 1-6.

56. A. J. Lennox and G. C. Lloyd-Jones, Angew. Chem. Int. Ed., 2013, 52, 7362-7370.

57. N. N. Murthy, M. Mahroof-Tahir and K. D. Karlin, J. Am. Chem. Soc., 1993, 115, 10404-10405.

58. A. Bhattacharya, V. Suarez, V. Tamez Jr and J. Wu Tetrahedron Lett., 2006, 47, 3221-3223.

59. P. Tundo, Pure Appl. Chem., 2000, 72, 1793-1797. 60. M. Kidwai, S. Saxena, M. K. R. Khan and S. S. Thukral, Bioorg. Med. Chem. Lett., 2005, 15, 42954298.

61. Y. Gu, J. Barrault and F. Jérôme, Adv. Synth. Catal., 2008, 350, 2007-2012.

62. Y. Gu and F. Jérôme, Green Chem., 2010, 12, 1127-1138.

63. A. Wolfson, C. Dlugy, Y. Shotland and D. Tavor, Tetrahedron Lett., 2009, 50, 5951-5953.

64. A. Díaz-Álvarez and V. Cadierno, Appl. Sci., 2013, 3, 55-69.

65. C. Vidal and J. Garcia-Alvarez, Green Chem., 2014 16, 3515-3521.

66. F. Chahdoura, L. Dubrulle, K. Fourmy, J. Durand, D. Madec and M. Gómez, Eur. J. Inorg. Chem., 2013, 2013, 5138-5144.

67. A. Wolfson and C. Dlugy, Chem. Pap., 2007, 61 228-232

68. A. Azua, J. A. Mata, P. Heymes, E. Peris, F. Lamaty, J. Martinez and E. Colacino, Adv. Synth. Catal., 2013, 355, 1107-1116.

69. A. Nirmala Grace and K. Pandian, Mater. Chem Phys., 2007, 104, 191-198.

70. Y.-W. Lee, S.-B. Han, A.-R. Ko, H.-S. Kim and K.-W. Park, Catal. Commun., 2011, 15, 137-140.

71. J. G. de Vries, in Selective Nanocatalysts and Nanoscience, Wiley- $\mathrm{VCH}$ Verlag $\mathrm{GmbH} \&$ Co. KGaA, 2011, pp. 73-103.

72. R. L. Cook, H. E. King, C. A. Herbst and D. R. Herschbach, J. Chem. Phys., 1994, 100, 5178-5189.

73. T. Watanabe, N. Miyaura and A. Suzuki, Synlett, 1992, 1992, 207-210.

74. S. Kozuch and J. M. L. Martin, ACS Catal., 2012, 2 2787-2794.

75. G. K. Rao, A. Kumar, J. Ahmed and A. K. Singh, Chem. Commun., 2010, 46, 5954-5956.

76. J. P. Wolfe, R. A. Singer, B. H. Yang and S. L. Buchwald, J. Am. Chem. Soc. , 1999, 121, 9550-9561. 77. N. Liu, C. Liu, B. Yan and Z. Jin, Appl. Organometal. Chem., 2011, 25, 168-172.

78. K. Karami, M. Hosseini-Kharat, Z. ShiraniSarmazeh, R. Zahedi-Nasab, C. Rizzoli and J. Lipkowski, J. Coord. Chem., 2016, 69, 763-778.

79. K. Wang, T. Yi, X. Yu, X. Zheng, H. Fu, H. Chen and R. Li, Appl. Organomet. Chem., 2012, 26, 342-346.

80. S. Shi and Y. Zhang, Green Chem., 2008, 10, 868872. 

Rev., 2014, 43, 412-443.

82 82. V. Derdau, R. Oekonomopulos and G. Schubert, J.Org. Chem., 2003, 68, 5168-5173.

83 83. L. A. McAllister, M. S. Hixon, J. P. Kennedy, T. J. Dickerson and K. D. Janda, J. Am. Chem. Soc., 2006, 128, 4176-4177.

84 84. G. L. Allsop, A. J. Cole, M. E. Giles, E. Merifield, A. J. Noble, M. A. Pritchett, L. A. Purdie and J. T. Singleton, Org. Process Res. Dev., 2009, 13, 751-759.

85 85. S. Günes, H. Neugebauer and N. S. Sariciftci, Chem. Rev., 2007, 107, 1324-1338.

86 86. Y.-J. Cheng, S.-H. Yang and C.-S. Hsu, Chem. Rev., 2009, 109, 5868-5923.

87 87. A. C. Grimsdale, K. Leok Chan, R. E. Martin, P. G. Jokisz and A. B. Holmes, Chem. Rev., 2009, 109, 8971091.

88 88. D. Crich, K. Sana and S. Guo, Org. Lett., 2007, 9, 4423-4426.

89 89. S. Frindy, A. Primo, M. Lahcini, M. Bousmina, H. Garcia and A. El Kadib, Green Chem., 2015, 17, 18931898.

909 90. Z. Zhou, F. Liu, Y. Huang, Z. Wang and G. Li, Int. J. Biol. Macromol., 2015, 77, 336-343.

9191. A. Ramesh, H. Hasegawa, W. Sugimoto, T. Maki and K. Ueda, Bioresour. Technol., 2008, 99, 3801-3809. 92. A. N. Nikoloski, K.-L. Ang and D. Li, Hydrometallurgy, 2015, 152, 20-32.

93 93. M. Zhu and G. Diao, J. Phys. Chem. C, 2011, 115, 24743-24749.

9494. M. Zha, J. Liu, Y.-L. Wong and Z. Xu, J. Mater. Chem. A, 2015, 3, 3928-3934. 